\title{
AN EMPIRICAL ANALYSIS ON EXPORT STATUS QUO AND INTERNATIONAL COMPETITIVENESS OF CHINESE FOOTWEAR PRODUCTS
}

\author{
Chunyu ZHANG* \\ Zhejiang Dongfang Polytechnic, Jinhai Road No. 433, Jinhai Park, Wenzhou Economic and Technological Development Zone, \\ Zhejiang Province, China, 252731850@qq.com
}

https://doi.org/10.24264/Ifj.18.3.2

\begin{abstract}
AN EMPIRICAL ANALYSIS ON EXPORT STATUS QUO AND INTERNATIONAL COMPETITIVENESS OF CHINESE FOOTWEAR PRODUCTS ABSTRACT. This paper firstly studies the current status quo from the points of view, such as the export scale, export quantity and trade partners, and then compares and measures the export competitiveness of footwear between China and other major exporting countries by using international market share, trade competitiveness index, revealed comparative \& competitive advantage index and product export unit price. The results show that the international market share of China's footwear industry has an absolute advantage, but the growth rate of the international competitiveness index has a sliding trend. The international competitiveness of China's footwear industry faces a certain challenge. The key to improve the international competitiveness of China's footwear industry lies in optimizing the export structure of products, developing diversified markets, paying attention to quality certification and export environmental protection requirements, etc. KEY WORDS: China's footwear industry, working shoes, international market share, international trade competitiveness, competitive advantage
\end{abstract}

O ANALIZĂ EMPIRICĂ PRIVIND STATU-QUOUL EXPORTULUI ŞI COMPETITIVITATEA INTERNATIONALĂ A ÎNCĂLTĂMINTEI DIN CHINA REZUMAT.Acest articol studiază în primul rând statu-quoul actual al exportului, cantitatea de export şi partenerii comerciali, apoi compară şi măsoară competitivitatea exporturilor de încălţăminte din China şi din alte ţări exportatoare majore, utilizând cota de piaţă internaţională, indicele de competitivitate, indicele avantajului competitiv şi comparativ şi un preţ unitar de export al produsului. Rezultatele arată că cota de piaţă internaţională a industriei de încălţăminte din China are un avantaj absolut, însă rata de creştere a indicelui de competitivitate internaţională are o tendinţă de scădere. Competitivitatea internaţională a industriei de încălţăminte din China se confruntă cu o anumită provocare. Cheia pentru îmbunătăţirea competitivităţii internaţionale a industriei de încălţăminte din China constă în optimizarea structurii exportului produselor, dezvoltarea pieţelor diversificate, acordarea atenţiei cerinţelor de calitate şi cerinţelor de protecţie a mediului etc. CUVINTE CHEIE: industria încălţămintei din China, încălţăminte de lucru, cota de piaţă internaţională, competitivitatea comerţului internaţional, avantaj competitiv

UNE ANALYSE EMPIRIQUE DU STATU QUO D'EXPORTATION ET DE LA COMPÉTITIVITÉ INTERNATIONALE DES CHAUSSURES CHINOISES RÉSUMÉ. Cet article étudie tout d'abord le statu quo actuel du point de vue des exportations, des quantités exportées et des partenaires commerciaux, puis compare et mesure la compétitivité à l'exportation des chaussures entre la Chine et les autres grands pays exportateurs en utilisant la part du marché international, l'indice de compétitivité, l'indice de l'avantage comparatif et concurrentiel et le prix unitaire à l'exportation des produits. Les résultats montrent que la part du marché international de l'industrie chinoise de la chaussure présente un avantage absolu, mais le taux de croissance de l'indice de compétitivité internationale a tendance à baisser. La compétitivité internationale de l'industrie chinoise de la chaussure est confrontée à un certain défi. La clé de l'amélioration de la compétitivité internationale de l'industrie chinoise de la chaussure réside dans l'optimisation de la structure d'exportation des produits, le développement de marchés diversifiés, l'attention accordée à la certification de qualité et aux exigences de protection environnementale, etc.

MOTS CLÉS : industrie chinoise de la chaussure, chaussures de travail, part du marché international, compétitivité du commerce international, avantage compétitif

\footnotetext{
* Correspondence to: Chunyu ZHANG, Zhejiang Dongfang Polytechnic, Jinhai Road No. 433, Jinhai Park, Wenzhou Economic and Technological Development Zone, Zhejiang Province, China, 252731850@qq.com
} 


\section{INTRODUCTION}

In view of the increasingly fierce competition in global footwear industry, this paper explores the current status of China's footwear products and compares the export competitiveness of these products against those manufactured by other countries. Besides, the author discussed how should China improve the international competitiveness of its footwear products and expand the share in the global market. The research findings will help China maintain its dominance in the footwear industry.

\section{STATUS QUO OF EXPORT OF WORKING SHOES IN CHINA}

\section{Scale of the Exports}

In 2008, the financial crisis swept the world, China's footwear exports have been deeply affected with the two consecutive years of small decline in exports. The government maintained growth, increased export support and boosted the confidence of export enterprises. Then from 2010 to 2014, the export of footwear increased year by year. China's exports of working shoes rose to $\$ 1002$ million in 2014 from $\$ 428$ million in 2009 , increased by 1.34 .

Table 1: 2008-2016 Export Amount of Footwear in China, US\$ million

\begin{tabular}{cccccccccc}
\hline Year & 2008 & 2009 & 2010 & 2011 & 2012 & 2013 & 2014 & 2015 & 2016 \\
\hline $\begin{array}{c}\text { Exports } \\
\text { Value }\end{array}$ & 561.6 & 428.2 & 611.1 & 771.2 & 784.8 & 896.2 & 1002.9 & 898.3 & 821.4 \\
\hline
\end{tabular}

From 2015 to 2016, under the influence of weak global economic recovery and lower market demand, there was a consistent negative growth in shoe exports in the world's major

\section{Export Quantity}

Table 2: 2008-2016 Export Quantity of Footwear in China, Million Pairs

\begin{tabular}{rrrrrrrrrr}
\hline Year & 2008 & 2009 & 2010 & 2011 & 2012 & 2013 & 2014 & 2015 & 2016 \\
\hline $\begin{array}{c}\text { Exports } \\
\text { Amount }\end{array}$ & 52.5 & 18.5 & 57.1 & 64.9 & 63.7 & 72.1 & 43.2 & 34.2 & 53.6 \\
\hline
\end{tabular}

From 2008 to 2016, the export quantity of Chinese working shoes is huge. There was an uneven trend of first increasing, then declining and then rising again. In 2013, the export quantity of shoes reached the highest of 72.1 million pairs in the history. As can be seen from Table 2, the export of Chinese working shoes experienced two difficult periods. In 2009, the export of footwear products fell to 18.5 million pairs, down by $65 \%$ over the same period of 2008. Exports fell to 34.2 million pairs in 2015, down by $21 \%$ from the same period in 2014 . footwear exporting countries and China. China's export amount fell to 898 million dollars, and further declined to 821 million dollar in 2016.

Table 3: 2016 Major Export Countries of Chinese Footwear

\begin{tabular}{ccccccc}
\hline Export Countries & USA & UK & Chile & Germany & $\begin{array}{c}\text { The United Arab } \\
\text { Emirates }\end{array}$ & Italy \\
\hline $\begin{array}{c}\text { Exports (USD } \\
\text { million) }\end{array}$ & 175.2 & 115.8 & 40.3 & 32.9 & 31.3 & 28.6 \\
\begin{tabular}{c} 
Proportion (\%) \\
\hline
\end{tabular} & 21 & 14 & 5 & 3.8 & 3.8 & 3.5 \\
\hline
\end{tabular}


As can be seen from Table 3, the main countries of China's footwear exports in 2016 were the United States, the UK, Chile, Germany, the United Arab Emirates and Italy, which accounted for $51.7 \%$ of China's total footwear exports. The United States, as one of the world's leading consumer goods markets, still has a clear import dependency on China's clothing and footwear, with imports of working shoes reaching US $\$ 1.75$ million, or $21 \%$, in 2016 . EU countries are still the main export countries of China's working shoes. The shares of South America and Middle East countries rose slightly.

\section{RESEARCH METHODS AND SOURCES OF DATA}

The data of this paper mainly comes from the United Nations Commodity Trade Statistics Database, the official website of WTO, China Statistics Yearbook and the websites of the Ministry of Commerce and National Bureau of Statistics of the People's Republic of China. Considering the continuity and availability of statistical data and the need of research, this study defines the statistical range of footwear products as "cowhide working shoes" (Commodity specification includes mid-back, cowhide upper, PU sole, without brand and others), HS code is 6403400.90 , mainly including mid-back safety shoes, metal head boots, labor protection shoes, cold boots, etc.

Table 4: 2008-2016 International Market Share of Working Shoes Exported from Major Countries in the World, \%

\begin{tabular}{ccccccc}
\hline Year & China & Italy & Germany & France & Indonesia & India \\
\hline 2008 & 31.98 & 19.02 & 6.95 & 7.17 & 3.23 & 1.29 \\
2009 & 30.17 & 22.83 & 7.08 & 6.01 & 2.83 & 0.61 \\
2010 & 34.05 & 19.98 & 6.38 & 5.11 & 3.95 & 1.65 \\
2011 & 35.82 & 18.26 & 6.10 & 4.53 & 3.91 & 1.39 \\
2012 & 38.59 & 17.12 & 5.74 & 3.58 & 4.07 & 0.89 \\
2013 & 38.58 & 15.41 & 5.24 & 3.02 & 3.91 & 1.74 \\
2014 & 39.11 & 14.46 & 5.14 & 2.66 & 3.67 & 2.52 \\
2015 & 39.97 & 14.34 & 5.28 & 2.23 & 3.63 & 2.36 \\
2016 & 37.76 & 15.86 & 5.48 & 2.12 & 4.85 & 3.64 \\
\hline
\end{tabular}

According to the calculation, the total market share of China, Italy, Germany, France, Indonesia and India reached $69.71 \%$ in 2016, which was $2 / 3$ of the global export of working shoes. From 2010 to 2016, China's international market share of working shoes has always been ranked first in the world with its annual

\section{ANALYSIS OF INTERNATIONAL COMPETITIVENESS OF CHINA'S WORKING SHOES}

According to the data of the United Nations Trade Statistics Database, in recent years, China, India, and Indonesia in Asia, Italy, Germany and France are the main export countries of the world working shoes. This study sorts out the opinions on international competitiveness, collects relevant data, and uses international market share, trade competitiveness index, revealed comparative \& competitive advantage index and product export unit price to compare and measure the export competitiveness of footwear products between China and several other major exporting countries. Then, the relevant measures and suggestions to improve the international competitiveness of China's footwear exports are explored.

\section{International Market Share}

The international market share is the proportion of an industry or a product's total export to the world's total export. The greater the proportion is, the stronger the international competitiveness of the industry or the product of the country, and vice versa.

average share of $38.70 \%$, and international competitiveness is the strongest. This is mainly due to the fact that as a large producer of light industrial products, China has formed a complete industrial chain in the fields of R\&D and design, material development, technical application, and production and processing. Each link has reached 
a relatively high level of proficiency, and formed relatively high overall production efficiency. With a large export scale, it far exceeds other countries. In the next few years, China's export of working shoes will continue to maintain its large market share.

At the same time, the market share of footwear design and production in the older countries such as Italy, Germany and France tends to decline, and France had the largest decline and plummeted from $7.17 \%$ in 2010 to $2.12 \%$ in 2016 . The Southeast Asian countries (Indonesia and India) benefit from the global shoe-making pattern shift, the shoe-making industry has obtained the unprecedented development and grabbed the low-grade market that originally belongs to China, and their market share presents the obvious rising trend, reducing the gap with China and becoming China's potential competitors.

\section{Trade Competitiveness Index}

The trade competitiveness index (TC index) is the ratio of the difference between the import and export trade of an industry or a product in a country to its total import and export trade, which reflects the competitive advantage and disadvantage of a certain kind of product or industry in a country relative to the same product in other countries on the world market.

Table 5: 2008-2016 Export Competitiveness Index of Working Shoes in Major Countries of the World

\begin{tabular}{ccccccc}
\hline Year & China & \multicolumn{1}{l}{ Italy } & Germany & France & Indonesia & India \\
\hline 2008 & 1 & 0.19 & -0.26 & -0.16 & 0.92 & 0.95 \\
2009 & 1 & 0.20 & -0.23 & -0.23 & 0.89 & 0.91 \\
2010 & 1 & 0.14 & -0.28 & -0.28 & 0.72 & 0.97 \\
2011 & 1 & 0.13 & -0.26 & -0.27 & 0.65 & 0.96 \\
2012 & 1 & 0.18 & -0.23 & -0.26 & 0.58 & 0.94 \\
2013 & 1 & 0.20 & -0.23 & -0.30 & 0.61 & 0.96 \\
2014 & 1 & 0.18 & -0.19 & -0.37 & 0.64 & 0.98 \\
2015 & 0.99 & 0.26 & -0.19 & -0.38 & 0.58 & 0.98 \\
2016 & 0.99 & 0.27 & -0.17 & -0.44 & 0.69 & 0.98 \\
\hline
\end{tabular}

The policies of encouraging exports and restricting imports are prevalent in the non-developed countries, so that the trade competitiveness index cannot accurately reflect the international competitiveness of products. It can be seen from Table 5 that Asian countries (China, Indonesia and India) are all performing well, China and India have stable export scale, their trade competitiveness indexes approached or maintained at 1 over the years, and their export of footwear products has a pattern of output-type vertical division of labor, with very small import proportion, the strongest international export competitiveness, and very obvious competitive advantage. The trade competitiveness indexes of the two countries are similar, with a strong competitive relationship. The value of Indonesia's trade competitiveness index of working shoes, shows that Indonesia's export of working shoe has been recognized by the global market and has a strong international competitiveness.
In European countries, Italy's trade competitiveness index hovers between 0.13 and 0.27 , which rises slowly, and its shoe production efficiency is higher than the international level, indicating a competitive advantage in the world. The TC index of Germany and France is negative, indicating that the production efficiency of this kind of shoes in two countries is lower than the international level, and the import of working shoes is higher than the export, showing a pattern of input vertical division of labor.

\section{Revealed Comparative Advantage}

The Revealed Comparative Advantage Index (RCA), proposed by Balassa (1965), refers to the export-relative performance index, which excludes the influence of the fluctuation of national total export and the fluctuation of global total export, and can better reflect the relative advantages of a country's export of an industry compared with the world's average export level. 
Table 6: 2008-2016 Revealed comparative advantage index of export of working shoes from major countries in the world

\begin{tabular}{ccccccc}
\hline Year & China & Italy & Germany & France & Indonesia & India \\
\hline 2008 & 3.50 & 5.49 & 0.74 & 1.89 & 3.69 & 1.14 \\
2009 & 3.07 & 6.87 & 0.77 & 1.58 & 2.97 & 0.41 \\
2010 & 3.24 & 6.51 & 0.75 & 1.50 & 3.76 & 1.13 \\
2011 & 3.89 & 7.19 & 0.74 & 1.39 & 3.45 & 0.83 \\
2012 & 3.38 & 6.13 & 0.73 & 1.15 & 3.85 & 0.55 \\
2013 & 3.25 & 5.53 & 0.68 & 0.99 & 3.99 & 0.96 \\
2014 & 3.09 & 5.05 & 0.63 & 0.87 & 3.86 & 1.47 \\
2015 & 2.84 & 5.06 & 0.64 & 0.73 & 3.89 & 1.44 \\
2016 & 2.77 & 5.29 & 0.63 & 0.67 & 5.17 & 2.15 \\
\hline
\end{tabular}

Italy is a tradidional shoe making country with a high level of exports. With its superb leather-making technology, improved design, perfect hand-making skills and the combination of comfort and beauty, Italian shoes have always been popular among consumers, and thus Italy firmly controls the high-grade market of the global footwear industry. As can be seen from Table 6, Italy's revealed comparative advantage has been maintained above 5 , and its overall position of superiority is unshakable. Indonesia, in second place, showed a steady and upward trend, with a leap-forward growth to 5.17 in 2016, and only 0.08 points lower than Italy. In contrast, China's revealed comparative advantage index as a whole shows a slow downward trend, in 2011 and with fluctuations, falling to 2.77 in 2016, which shows that China's comparative advantage was obvious and competitive in the early stage, but not optimistic in the next few years.

\section{Comparative Advantage Index}

The CA index evolved from the RCA index. Taking into account the import factors, it subtracts the import comparative advantage from the export comparative advantage of the industry, and to some extent, makes up for the deficiency of the trade competitiveness index and the revealed comparative advantage index, making the measurement of international competitiveness more realistic. When the $C A$ index $\geq 0$, the product has the revealed competitive advantage, the larger the value is, the more obvious the advantage is. If the CA index $<0$, the product does not have the revealed competitive advantage, the smaller the value is, the more obvious the competitive disadvantage is.

Table 7: 2008-2016 Revealed competitive advantage index of export of working shoes from major countries in the world

\begin{tabular}{ccccccc}
\hline Year & China & Italy & Germany & France & Indonesia & India \\
\hline 2008 & 3.49 & 2.38 & -0.57 & -0.01 & 3.54 & 1.13 \\
2009 & 3.07 & 2.85 & -0.53 & -0.35 & 2.79 & 0.4 \\
2010 & 3.24 & 4.31 & 0.01 & 0.43 & 3.43 & 1.12 \\
2011 & 3.39 & 2.96 & -0.64 & -0.46 & 2.68 & 0.82 \\
2012 & 3.38 & 2.26 & -0.55 & -0.32 & 1.95 & 0.54 \\
2013 & 3.24 & 1.79 & -0.55 & -0.46 & 3.09 & 0.95 \\
2014 & 3.08 & 1.46 & -0.55 & -0.59 & 3.09 & 1.46 \\
2015 & 2.82 & 2.09 & -0.43 & -0.56 & 2.90 & 1.43 \\
2016 & 2.75 & 2.09 & -0.41 & -0.93 & 4.23 & 2.14 \\
\hline
\end{tabular}

As can be seen from the table, Germany and France's CA index is less than 0 , which indicates a weak competitive advantage. France's CA index fell to -0.93 in 2016, the lowest in years. The revealed competitive advantage indexes of the other four countries are positive, indicating that the footwear exports of China, Italy, Indonesia, India and other countries have significant competitiveness and competitive advantages, but there are great differences in the values, with fluctuations. China's CA index is basically the same as the RCA index, indicating 
that the import of working shoes is basically negligible and has little impact on exports.

From the development trend of the revealed comparative advantage, Italy and China as a whole show a declining trend, and its revealed competitive advantage weakens and international competitiveness declined. Indonesia and India, on the other hand, show a marked upward trend after the fall, and Indonesia is the most prominent, with the fall ending abruptly in 2015 and rising suddenly to 4.23 in 2016, showing a strong competitive momentum.

\section{Comparison of Unit Price of Working Shoes for the Export}

Price is one of the important factors reflecting the international competitiveness of products.

Table 8: 2008-2016 Unit price of working shoes for the export from major countries of the world

\begin{tabular}{ccccccc}
\hline Year & China & Italy & Germany & France & Indonesia & India \\
\hline 2008 & 10.70 & 25.00 & 22.76 & 30.12 & 22.76 & 13.13 \\
2009 & 23.15 & 24.93 & 23.15 & 30.28 & 23.15 & 13.34 \\
2010 & 10.70 & 24.70 & 26.82 & 28.68 & 26.82 & 26.82 \\
2011 & 11.88 & 27.53 & 26.79 & 26.79 & 26.79 & 14.52 \\
2012 & 12.33 & 26.11 & 23.93 & 30.24 & 23.93 & 13.48 \\
2013 & 12.43 & 28.04 & 23.93 & 30.66 & 23.93 & 14.95 \\
2014 & 23.21 & 29.17 & 23.21 & 26.86 & 23.21 & 16.24 \\
2015 & 26.24 & 25.27 & 26.24 & 16.13 & 42.67 & 14.16 \\
2016 & 15.32 & 25.89 & 15.31 & 17.01 & 15.33 & 15.21 \\
Unit Price & 15.32 & 26.29 & 23.57 & 26.31 & 25.40 & 15.78 \\
\hline
\end{tabular}

In 2016, under the recession ofinternational demand market, the export quantity of working shoes in several major export countries has been increased against the falling trend, which shows that the global demand for working shoes still has a certain space; but with the exception of Italy, the unit price of shoes consistently and dramatically fell.

Through calculation and comparison, it is known that the average price of China's working shoes for export has been at a low level for a long time, and the average export unit price (\$15.32) over the years has not only been lower than the world average level, but also lower than that of Indonesia (\$25.40), and only slightly higher than that of India (\$15.78). On the one hand, it shows that China's shoe-making export enterprises continue to enjoy the traditional industrial advantages and labor advantages, and greatly increased the comparative advantages of the middle- and low-grade products of working shoes through large-scale production, cost reduction and other ways; on the other hand, it also shows that China's footwear products are low in added value and still rely on "low grade, low quality, and low price" to penetrate the international market.

\section{CONCLUSION AND SUGGESTIONS}

After more than 20 years of developments, China's footwear exports have reached about $65 \%$ the world's total shoe exports, and thus China has become the world's largest producer and exporter, mainly targeting markets such as the United States, the European Union, Russia and Japan. However, in recent years, with the appreciation of exchange rate and the rigid increase of essential productive factors (like labor \& material cost) as well as the unshakable dominance of Italy and other exporters, Southeast Asian competitors are gradually rising, the international competitiveness of China's footwear industry has been challenged, so that China maintains its competitive advantage.

\section{Optimize the Product Structure, and Increase the Added Value of Products}

In the course of many years' development, China's shoe-making industry has formed a perfect industrial chain. In the international market, China obtained more than $1 / 3$ share of the international market share by the way of "low price". Its export quantity accounts for $65 \%$ of the world, and the space for the promotion of its share is limited. The export footwear products 
are mainly middle- and low-grade products, with low price and low profits. In the development process of Chinese shoe-making and export enterprises, under the premise of keeping the steady quantity and amount of exports, we should vigorously carry out technological innovation, pay attention to the inherent quality of the products and the fashion, function and environmental protection of the products, optimize the product structure, and improve the added value of products. Towards quality orientation instead of quantity orientation, the proportion of middle- and low-grade products should be reduced to improve the comprehensive international competitiveness of products.

\section{Actively Adjust the Market Structure and Open up Diversified Markets}

With lower prices and good quality, China's footwear products are mainly exported to the United States, the European Union, Russia and other export destination countries, and have a steadily rising market share. China has a deep market overlapping with several other major export countries, which intensifies the competition.

Therefore, while consolidating the original markets, it is imperative to seek and exploit the emerging markets and further promote the diversified market share. The Belt \& Road spans 65 countries and regions on the three continents of Asia, Europe and Africa, forming a closed onshore and offshore economic loop. The countries along the line have a large population, totally about 4.5 billion, and their total economic output accounts for over $50 \%$ of global economic output. They have a broad market prospect and strong demands for China's light industrial products. With the help of the strategic opportunity of the Belt \& Road, the Chinese shoe-making and shoe exporting enterprises study the demands for shoe products along this line, divide the key markets, base themselves on the advantages of overseas regions, expand the radiation circle, form a market development pattern with multi-support, and get rid of the difficulties of being restrained by the European and American markets.

\section{Pay Attention to Quality Certification and Export Environmental Protection Requirements}

In recent years, trade protectionism prevails in European and American countries, which construct technical barriers to strictly control and test raw materials and possible harmful substances produced in the production process. China's footwear exports have become a high-risk area of trade friction, and exports are seriously hindered. Following the EU countries, China's other main export markets, such as Saudi Arabia in the Middle East, implement market access system for China's imported footwear products without certificates, which makes the goods refused to enter after being shipped to the port of entry. Chinese shoe-making and shoe export enterprises must actively understand and study the environmental standards, certification standards, and project testing of importing countries, increase investment in environmental protection, standardize their own business behavior, comply with industry rules, and apply to authorities for certification of various environmental protection labels to obtain market passes, so as to have a foothold in the international market.

\section{Implement the "Brand-oriented" Strategy}

After the transfer of the early world shoemaking center to Korea, Japan and Taiwan, Italy carried out the strategy of "quality orientation instead of quantity orientation" for product upgrading and brand building. Italian shoes become the symbol of high-grade which dominate the world market. It is difficult to take a long way by copying others' design and having low-price competition. Chinese enterprises must fully realize that establishing the brand recognized by the international market is the only way for the long-term development of the enterprises and the only way to maintain and improve the international competitiveness of Chinese footwear products. Implementing "brandoriented", that enterprise studies the main market of product sales pertinently, accurately defines the attributes, culture, consumers and other factors of the brand to be promoted, and makes good design and manufacture of the products, so as to be approved by the consumers. 


\section{REFERENCES}

1. Yu, D.J., Analysis of Customs Import and Export Data of Chinese Footwear Products in 2016, Shoes, 2016, 4, 30-38.

2. Lu, H., Wang, S.C., Analysis of the Competitiveness of Chinese Shoe Industry Based on the Principal Component Factor Analysis, Journal of Shaanxi University of Science and Technology, 2017, 35, 4, 185-190.

3. Zhang, J.C., The Theory and Method of International Competitiveness Evaluation. Beijing: Economic Science Press, 2002, 119125.

4. Wang, Q., A Summary of the Theory and Evaluation System of Contemporary International Competitiveness, Foreign Social Sciences, 2006, 6, 32-38.
5. Yu, Q., Gao, J.T., Research on the International Competitiveness of Chinese Footwear Industry under the Background of Financial Crisis, Foreign Trade and Economic Trade, 2010, 2, 20-23.

6. Zhang, J., A Comparative Study of the International Competitiveness of Chinese and Italian Footwear Industry, Journal of Zhejiang University of Technology, 2011, 1, 91-95.

(C) 2018 by the author(s). Published by INCDTPICPI, Bucharest, RO. This is an open access article distributed under the terms and conditions of the Creative Commons Attribution license (http:// creativecommons.org/licenses/by/4.0/). 